\title{
Design of a new rotary dobby mechanism
}

\section{REZUMAT - ABSTRACT}

\section{Proiectarea unui nou mecanism de țesere cu ratieră rotativă}

\begin{abstract}
Mecanisme speciale cu camă care necesită o tehnologie avansată au fost utilizate în dispozitivul de acționare a noilor ratiere rotative. Electromagneții sunt în general preferați în mecanismele de selecție, dar aceștia măresc costurile de producție și fac mai dificilă întreținerea. Această lucrare își propune să conceapă un nou tip de ratieră rotativă, diferită de celelalte ratiere. În primul rând, au fost elaborate proiectarea și sinteza unui nou mecanism de acționare cu opt poziții, la același nivel și la nivel dublu pentru mișcarea oscilantă de $180^{\circ}$. Rezultatele cercetării au arătat că atât valorile teoretice, cât și cele experimentale ale unghiurilor de staționare ale mecanismului de acționare sunt compatibile una cu cealaltă. Astfel, s-a propus ca mecanismele proiectate să poată fi utilizate în locul mecanismelor speciale cu came la ratierele rotative. Pistoanele pneumatice și elementele de blocare au fost utilizate în mecanismul de selecție a ratiere rotative dezvoltate în acest studiu. În timpul testelor de performanță, s-a observat că pistonul pneumatic și elementele de blocare pot fi utilizate în locul electromagneților, acționând în armonie unul cu celălalt. Ca o concluzie, atunci când a fost testată performanța de lucru a ratierei, s-a confirmat că aceasta a funcționat cu o performanță ridicată și în mod durabil, cu toate mecanismele componente. În plus, procesul de formare a rostului a fost efectuat cu precizie. În cele din urmă, a fost proiectată și produsă o nouă ratieră rotativă, care a fost ușor de construit cu costuri reduse.
\end{abstract}

Cuvinte-cheie: țesere, formare a rostului, ratieră, proiectarea mecanismului, ratieră rotativă

\section{Design of a new rotary dobby mechanism}

Special cam mechanisms which require advanced technology are used in the drive mechanism of nowadays rotary dobbies. Electromagnets are generally preferred in the selection mechanisms which increase the cost of production and make the maintenance more difficult. This work aims to design a new rotary dobby different from the other dobbies. First of all, the design and synthesis of a new drive mechanism with eight members, equal and double standby at $180^{\circ}$ oscillating motion was developed. The results of the research revealed that both the theoretical and the experimental values of the waiting angles of drive mechanism are compatible with each other. Thus, it has been proposed that designed mechanism can be used instead of the special cams mechanisms in the rotary dobbies. Pneumatic pistons and locks have been used in the selection mechanism of rotating dobby developed in the study. During the performence tests, it has been observed that the pneumatic piston and locks can be used instead of the electromagnets by providing that they work in harmony with each other. As a conclusion, when the working performance of dobby was observed, it was confirmed that dobby worked with a high performance and durably with all of its mechanisms. Additionally the shedding process was precisely carried out. Finally a new rotary dobby which was easy to construct with low cost has been designed and produced.

Keywords: weaving, shedding, dobby, design of mechanism, rotary dobby

\section{INTRODUCTION}

Woven fabrics are formed by crossing of weft and warp yarn groups under and over each other. In order for the weft yarns to be connected to the warp threads, it is necessary to separate the warp yarn groups into two different layers. This layer with a triangular section is called the shed [1-3].

The shed types are classified in three groups:

1. According to the geometric form of the shed; symmetrical opening sheds at the top, bottom and both sides [4-5].

2. According to the layout of the weft yarns in the shed; regular (clean), irregular (dirty) and semiregular (semi-clean) sheds [6-8].

3. According to shape of shed closing; open, semiopen, bottom and middle position closed sheds [7-8].

Shedding process directly affects the weaving performance and speed. Many different shedding mecha- nisms have been developed for the shed opening systems. These are cam, dobby and jacquard shed opening mechanisms. Nowadays, rotary dobbies have been developed for the shedding operations in high-speed modern weaving machines. The rotary dobbies are the dobby mechanisms that convert the rotational motion of the main shaft of the weaving machine into a up-down motion of the frames by means of various gears-arms and eccentrics (cam).

\section{Working principle of the classic rotary dobby}

A classic rotary dobby consists of three main parts:

1. Drive mechanism with eccentrics (cams);

2. Selection mechanism for determining the position of the frames by cutting the connection between the eccentric shaft and the eccentric according to the weave pattern;

3. The part that generates the variable dobby shaft motion (modulator) [9]. 
In recent years it has been observed that the speed of rotary armatures has reached $1000 \mathrm{rpm}$ and above. Thus, it is possible to operate the rotary dobbies at high speeds in air-jet and water-jet weaving machines [10]. Nowadays electronically controlled rotary dobbies are used.

In rotary doobies, the one-way rotary motion obtained from the drive mechanism must be transmitted to the main shaft of the machine. In order to achieve this kind of movement, the cam mechanism with the special structure rotating in the constant velocity is used in the drive mechanism of the rotary dobbies. In addition to the cam mechanisms in the dobby drive mechanism, servo-motor, arm and gear-arm mechanisms have also been used [11].

New dobby designs have been reached in research on rotary dobbies. Some of these are listed below:

- Shape enclosed cam pair has been used and proposed in the developed new rotary dobby's drive mechanism [5].

- New methods have been proposed using the $A D A M S \circledR$ program in the design of the rotary dobby drive mechanism cams [12].

- New cam profile design and synthesis are proposed for the regulation of the motion profiles of the cam mechanisms used in the dobbies and reducing the residual vibrations of the frames [13].

- Special eight-arms mechanism has been synthesized and proposed instead of the cams used in the drive mechanism of the dobbies [14].

- New electronic selection mechanism is proposed instead of the electronic selection mechanism used in rotary dobbies. In this mechanism, the number of moving members is reduced and the test set is run smoothly [15].

Furthermore, studies have been carried out related to the subject and it has been concluded that negative control dobbies managed by micro processors will be replaced by nowaday's positive dobbies and information has been obtained that the shedding mechanisms driven by the servo motors may be widespread in the near future $[9,16]$. The prominent feature about the new rotary dobby mechanism developed for the study and is the drive mechanism and the selection mechanism which makes it different from the before developed rotary dobby mechanisms.

\section{NEW DESIGNED ROTARY DOBBY}

Designing drive mechanism of new rotary dobby This study includes the design and synthesis of the mechanism proposed as an alternative to the special cam mechanisms has been developed in the drive mechanism of the rotary dobbies used today. The mechanism is designed and produced to have 8 members, to make equal and double standby swing motion at $180^{\circ}$. The kinematic scheme of the mechanism and mounted status of the drive mechanism right and left sides are shown in figure 1.

The design of the dobby drive mechanism has been theoretically determined by the SAM $6.1 \circledR$ program. The position, velocity and acceleration of the mechanism are analyzed. Then the mechanism has been produced, the assembly and working experiments have been completed and the analysis results have been obtained. The results of the analysis were given in the results and discussionchapter.

\section{Designing selection mechanism of new rotary dobby}

Selection mechanism of the new rotary dobby consists of main shaft of double standby with $180^{\circ}$ rotational motion which was indicated with number "1", fixed on this shaft discs of numbered 2, locks mounted on discs numbered 4 , eccenstric of numbered 3 , arm numbered 5 , output lever of numbered 6 , pneumatic piston of numbered 7 , pressuring arms of numbered 8 , cam of numbered 9 and dobby blade of numbered 10 . Working principle of rotary dobby selection mechanism and mounted status of the mechanism are shown at figure 2 . The selection process occurs while waiting on the left and right edges every $180^{\circ}$ of rotation of the dobby main shaft.

Mechanism's working principle: While the main shaft (1) stands on the left edge pneumatic pistons (7) are drawn back with electronic signals coming from the pattern wheel (the pattern wheel isn't shown in the figure 2). The cam (9) which is started to rotate clockwise and its effect on the pressuring arms (8) reduces and the pressuring arm (8) can't push the locks (4). In this case, the locks (4) moves out of the center of the disc (2) with the impact of springs and the locks are attached to the dobby blade (10) on the left side. The connection between the disc (2) and the eccentric (3) are established. The main shaft (1), the disc 


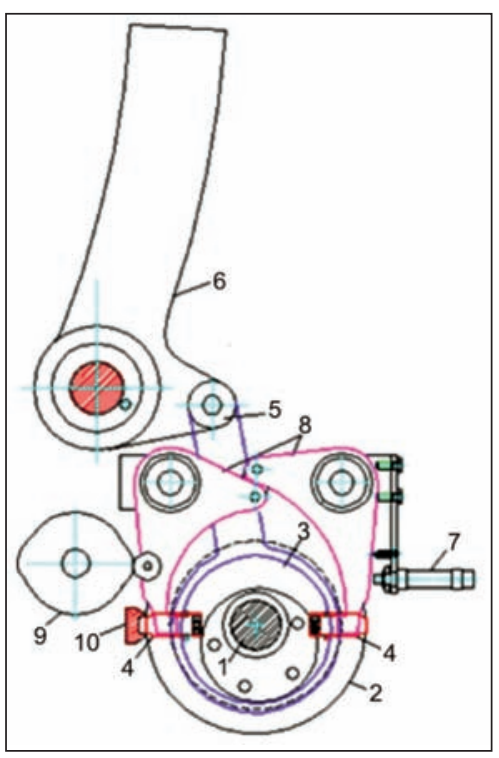

a

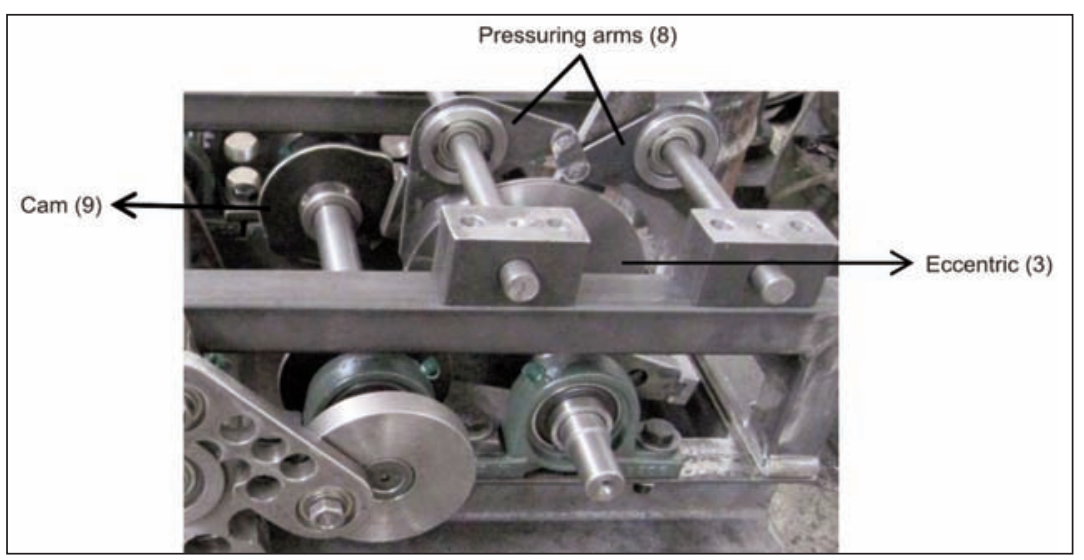

c

Fig. 2. Selection mechanism: $a$ - output lever (6) on the right; $b$ - output lever (6) on the left; $c$ - mounted status of selection mechanism [11]

forward, the piston (7) and cam (9) compresses the pressuring arms (8) and pushes locks (4). In this case, locks (4) can't be attached to the dobby blade (10) on the right side and connection can't be made between disc (2) and cam (3) too. Thus, the eccentric (3) connected to the arm (5) and the arm (5) connected to the output lever (6) can't move. As a result, the frame connected to the output lever (6) doesn't move. Proposed rotary dobby selection process takes place twice every $180^{\circ}$ of rotation of the main shaft. In this case selection process has been two times faster than the oneway stand-up rotary dobbies. The technical drawing of the designed new rotary dobby and its mounted status are shown in figure 3.

\section{RESULTS AND DISCUSSION}

After the settings of the drive mechanism have been completed, the movements of the mechanism have been calculated by the SAM $6.1 \AA$ program. Coordinate, velocity and acceleration analyses have been conducted. The analysis graphs obtained in the SAM 6.1尺 program of the proposed mechanism are shown in figure 4.

When the figure 4 has been examined it is seen that from the diagram (1), the waiting angles of the output shaft in edge condition are $63^{\circ}$ in the right edge and $60^{\circ}$ in the left

(2), the eccentric (3) and the dobby blade (10) rotate $180^{\circ}$ at the counterclockwise together. Arm (5) connected to eccentric (3) makes the output lever (6) rotate from the right edge to the left edge position. Thus, the frame connected to the output lever (6) is also moved.

Re-selection process is performed when main shaft (1) of the dobby has been rotated $180^{\circ}$ and waiting on the right side. If the pneumatic piston (7) is pushed edge. These values, which are equal to 126 and $120^{\circ}$ of rotation of the main shaft of the weaving machine, are approximately equal to the values required for the reading and application of the dobby program. The angular displacement of the output shaft and the working speed were investigated in order to be able to perform the workability tests of the drive mechanism. Angle measuring devices with a measurement accuracy equal to $1^{\circ}$ has been installed to the input

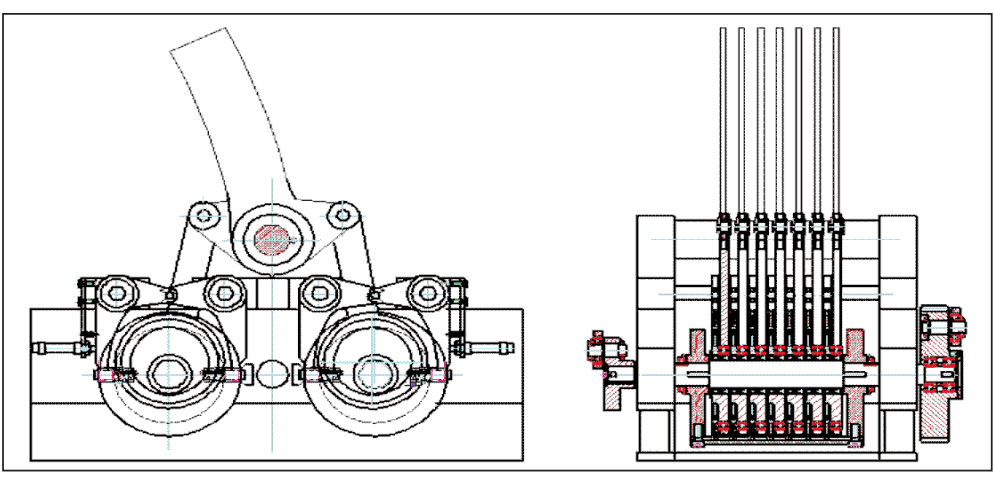

a

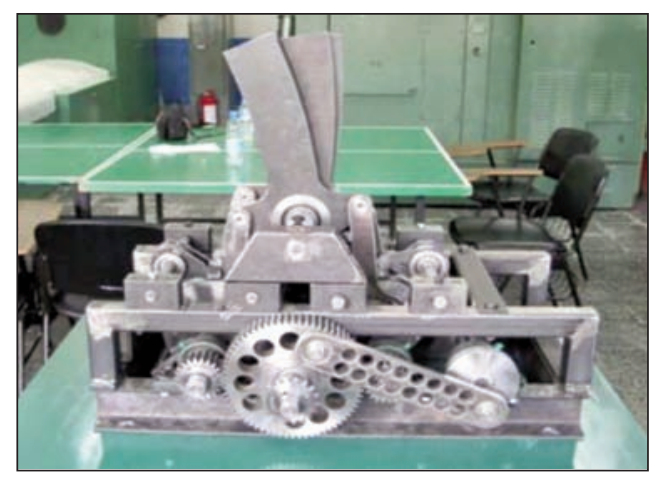

b

Fig. 3. Rotary dobby: $a$ - technical drawing of new dobby; $b$ - mounted status of new rotary dobby [11] 


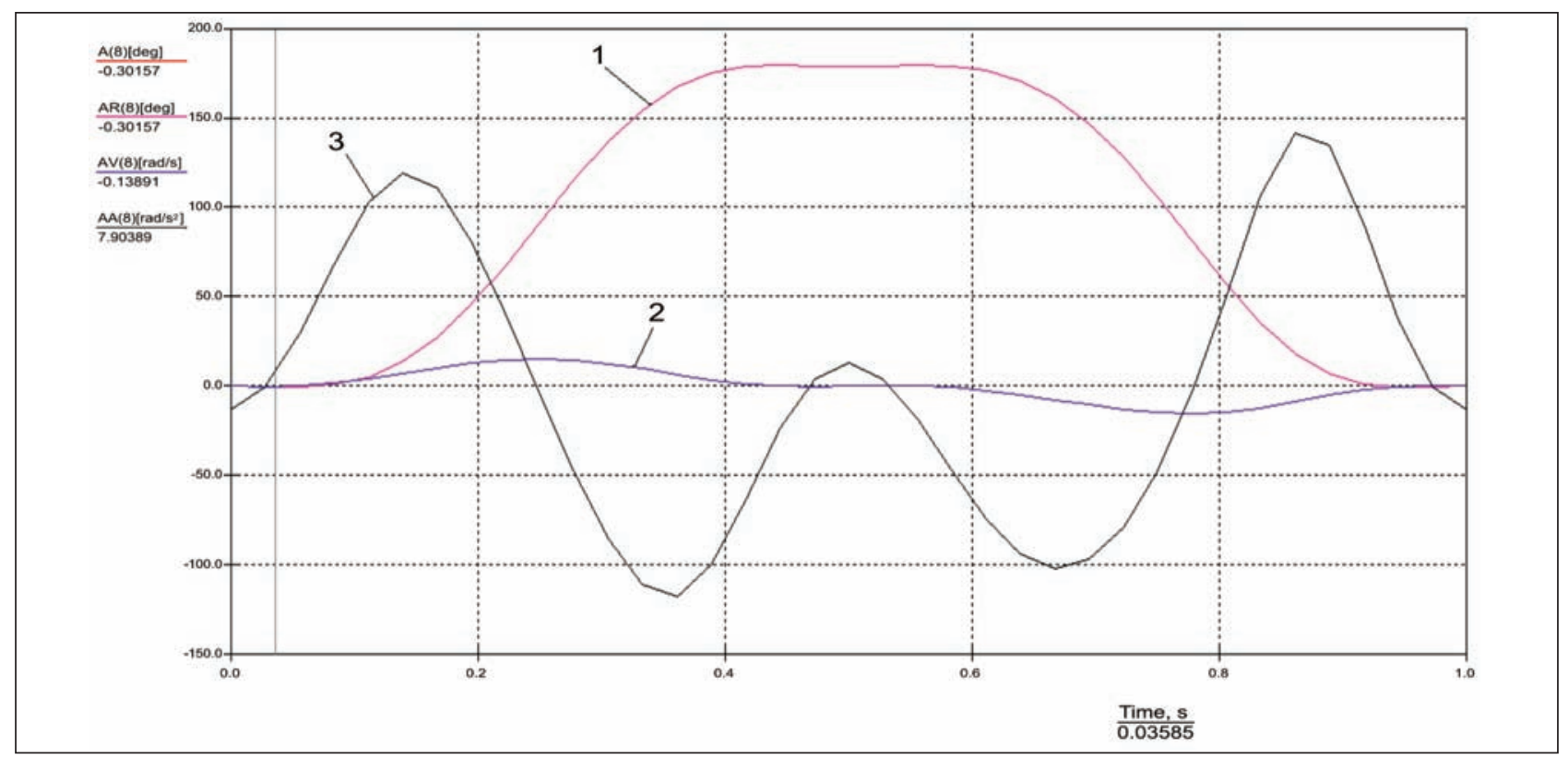

Fig. 4. The angular position (1), velocity (2) and acceleration (3) plots of the output shaft drawn in SAM 6.1® [11]

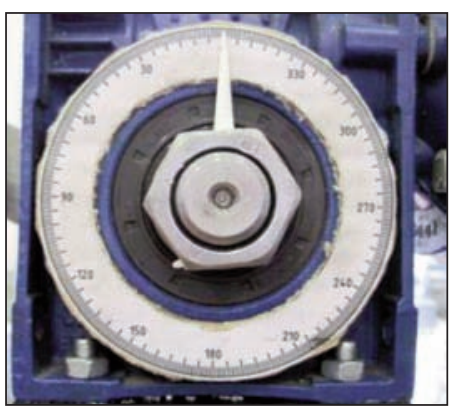

a

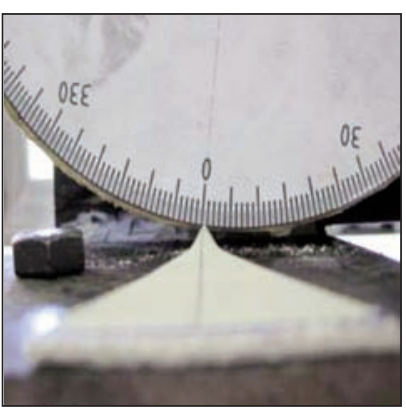

b

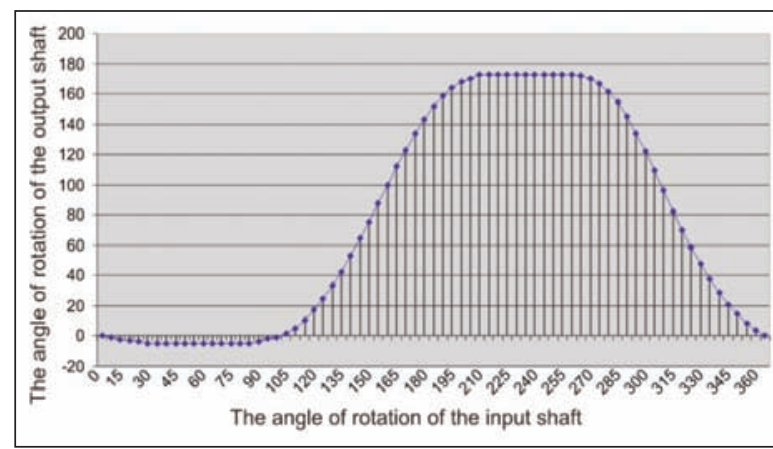

Fig. 6. Angular displacement diagram of the mechanism output shaft [11]

Fig. 5. Gunner's quadrants: $a$ - input shaft gunner's quadrant; $b$ - output shaft gunner's quadrant [11]

and output shafts of the mechanism for determining the angular displacement of the output shaft. The angle measuring devices are shown in figure 5 .

The angle of rotation of the output shaft was measured at every $5^{\circ}$ rotation angle of the input shaft for the workability experiments of the mechanism in practice. According to the obtained data, an angular displacement graph of the output shaft is plotted in

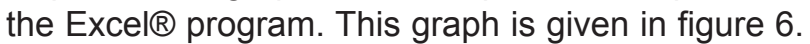
According to figure 6 , it is observed that, the output shaft draws a waiting motion curve at $360^{\circ}$ rotation of the input shaft. When this movement curve is examined, it is observed that the output shaft's waits while the input shaft of the mechanism is moving between the range of $25^{\circ}-80^{\circ}$ and $205^{\circ}-260^{\circ}$. This means that the output shaft is waiting approximately $55^{\circ}$ in both right and left edge positions. When the both graphs are analysed, the motion curve of the dobby drive mechanism and the motion curve obtained from the SAM $6.1 \circledR$ program are similar. It is also seen that the difference between the theoretical values of the waiting angle of the mechanism and the experimental values is slightly less than $5^{\circ}$. It is thought that this deviation between theoretical and practical values may be due to the spaces between the machine elements. In this way, it has been proposed that the newly designed mechanism can be used instead of the cam mechanisms used in the dobby machines.

\section{CONCLUSIONS}

Special cams are used to ensure the standby rotation of the dobby main shaft in the drive mechanism of classic rotary dobby. In this study, the design and synthesis of a new drive mechanism with eight members, equal and double standby $180^{\circ}$ oscillating motion is obtained. The results of the research revealed that both theoretical and the experimental values of the waiting angles are compatible with each other. Thus, it is proposed that the eight members' synthesized mechanism can be used instead of the special cam mechanisms in the rotary dobbies.

Additionally, pneumatic pistons working with electronic signals coming from pattern wheel is used in rotary dobby's selection mechanism has been developed in the study. As a result, the rotary dobby's selection mechanism developed in the study, differs from the classic rotary dobbies that work with elec- 
tromagnets. Afterwards, the dobby has been runned at different speeds in order to observe the states of the mechanisms. In the conducted experiments, it has been observed that, the standby angles of the drive mechanism have been consistent with the theoretical angles. Also the locks in the selection mechanism have been worked with the cams and the pneumatic pistons on time. It has also been found that, at all working speeds, the dobby mechanisms have been worked together durably. As a result, the basic constructional dobby drive mechanism and selection mechanism have been produced by using a standard machine element. Thus, the cost of the rotary dobby production has been reduced further and the maintenance has been made easier.

\section{ACKNOWLEDGEMENT}

We would like to express our appreciation to Scientific Research Projects Coordination Unit of Suleyman Demirel University (Turkey), (Project no: 2126-D-10) for the financial support.

\section{BIBLIOGRAPHY}

[1] Eren, R., Özkan, G., Karahan, M. Comparison of heald frame motion generated by rotary dobby and crank and cam shedding motions, In: Fibre Textile Eastern Europa. 2005, vol. 13, no. 4, pp. 78-83.

[2] Başer, G. DokumaTekniğiveSanatı. In: Cilt 1 (Technology and Art of Weaving) vol.1, Punto Publishing, 2004, pp. 1-150, İzmir, Turkey.

[3] Adanur, S. Handbook of Weaving, In: PA Lancaster: Technomic Publishing Company, 2001, pp. 1-429, USA.

[4] Lord, P., R., Mohammed, M.H. Weaving: Conversion of Yarn to Fabric, In: Merrow Publishing Co. Ltd., 1982, pp. 1-408, Manchester, England.

[5] Abdulla, G., Palamutçu, S., Hasçelik B., Soydan, S.A. Research and modernization of shedding mechanisms in weaving machines, In: DPT Project report, report no: 2003K120950, 2006, pp. 1-138, Ankara, Turkey.

[6] Talavasek, O., Svyatıy, V. Besçelnoçnie tkatskiye stanki. In: Legpromizdat, 1985, pp. 1-320. Moskow, Russia.

[7] Alpay, R. Dokumamakineleri. (Weaving machines), In: Uludağ Üniversitesi Yayınları (Bursa: Publication of Uludag University), vol.1, 1985, pp. 1-291, Bursa, Turkey.

[8] Eren, R. Design of shedding mechanisms, In: Uludag University, Institute of Science and Technology, Master's Thesis, 1987, pp. 1-132, Bursa.

[9] Eren, R. Dobby shedding mechanisms, In: Tekstil Maraton, 2000, pp. 46-55.

[10] Eren, R., Özkan, G., Turhan, Y. Kinematics of rotary dobby and analysis of heald frame motion in weaving process, In: Textile Research Journal, 2008, vol. 78, no. 12, pp. 1070-1079.

[11] Can, Ö. Investigation of the working performance of dobby shedding mechanism and a new dobby design, In: Suleyman Demirel University, Institute of Science and Technology, Ph.D. Thesis, 2012, pp. 1-190, Isparta.

[12] Lee, S., Shin, J., Lee, S.,D., Kim, D. Analysis and design of a driving mechanism for the cam type dobby system, In: Journal of Korean Fiber Society, vol. 41, no. 1, pp. 56-58.

[13] Kapucu, S., Bayseç S., Yarbasan M. Reduction of frame residual vibration by the shedding mechanism cam movement profile regulation. In: MakineTek, 2007, pp. 78-82.

[14] Abdulla, G., Yürik D. Synthesis of lever mechanism which makes an oscillation movement below $180^{\circ}$ for rotary dobby machine. In: The 12th International Conference on Machine Design and Production, September 5-8, 2006, Muğla, Turkey, pp. 81-90.

[15] Abdulla, G., Palamutçu, S. Constructional Synthesis of RA-14 Rotational Dobby Programming - Locking Unit, In: 1. International Istanbul Textile and Textile Machinery Congress, 01-02 June 2006, İstanbul, Turkey, pp. 85-89.

[16] Gokarneshan, N., Jegadeesan, N., Dhanapal, P. Recent innovations in loom shedding mechanisms. In: Indian Journal of Fibre\&Textile Research, 2010, vol. 35, no. 1, pp. 85-94.

\section{Authors: \\ ÖZGÜN CAN ${ }^{1}$, GABILL ABDULLA ${ }^{2}$ \\ ${ }^{1}$ Suleyman Demirel University, Faculty of Fine Arts Department of Fashion and Design 32300, Çunur, Isparta, Turkiye \\ ${ }^{2}$ Suleyman Demirel University, Faculty of Engineering Department of Textile Engineering 32300, Çunur, Isparta, Turkiye \\ e-mail: ozguncan@sdu.edu.tr; gabilabdulla@sdu.edu.tr}

Corresponding author:

ÖZGÜN CAN

e-mail: ozguncan@sdu.edu.tr 